\title{
GLOCALIZATION OF REGIONAL INNOVATION DEVELOPMENT
}

\author{
Olga Iermakova ${ }^{1}$, Bożena Kamińska ${ }^{2}$, Dan Marius Voicilas ${ }^{3}$, Oleksandr Laiko $^{4}$, Olena Hetman $^{5}$, \\ Eleonora Zabarna ${ }^{6}$, Ihor Halytsia ${ }^{7}$
}

${ }^{1}$ Doctor of Economics, Associate Professor, Senior Researcher, Institute of Market Problems and Economic \& Ecological Research of the National Academy of Sciences of Ukraine, Odessa National Economic University, Ukraine, 65044, Odesa, Frantsuzskiy Boulevard,29, Phone: +38-067-346-37-38, Email: impeer@ukr.net.ORCID ID: 0000-0002-9815-3464

${ }^{2} \mathrm{PhD}$ in Economics, The London Academy of Science and Business, England, Email: biuro@bozenakaminska.pl. ORCID ID: 0000-0002-0654-870X

${ }^{3}$ Doctor of Economics, Associate Professor, Senior Researcher, Institute of Agricultural Economics Bucharest of the Romanian Academy, Email.dmvoici@yahoo.com. ORCID ID: 0000-0003-3411-8958

${ }^{4}$ Doctor of Economics, Senior Scientific Researcher, Institute of Market Problems and Economic \& Ecological Research of the National Academy of Sciences of Ukraine, Ukraine, Email: alexlayko@gmail.com. ORCID: 0000-0001-7082-0862

${ }^{5} \mathrm{PhD}$ in Economics, Institute of Market Problems and Economic \& Ecological Research of the National Academy of Sciences of Ukraine, Ukraine, Email: helenagetman24@gmail.com.ORCID: 0000-0002-7404-3738

${ }^{6}$ Doctor of Economics, Professor, Odesa National Polytechnic University, Ukraine, Email: eleonoraZ@ukr.net. ORCID ID: 0000-0002-2659-5909

${ }^{7}$ Doctor of Economics, Full Professor, University “KROK”, Ukraine, Email: igalica@ukr.net. ORCID ID: 0000-0002-1276-5743

Received 1708 2020; Accepted 04112020

\begin{abstract}
This paper summarizes the arguments within the scientific discussion on the issue of global-local interactions of a region and usage of its synergy for the innovation development. Glocalization concept provides combination of global and local issues of innovation development that is an competitive advantage for a region. The main purpose of the research is to determine paradigm shift from traditional to modern regional innovation policy under conditions of glocalization based on the modern European research, experience of European countries' regions and reveal prospects of its implementation in Ukraine. The relevance of the decision of this scientific research is that the concepts of globalization and comprehensive integration have reached their limits, it can be stated the beginning of the era of glocalization - global cooperation, focusing on local resources and local competitive advantages. Investigation of glocalization of regional innovation development in the paper is carried out in the following logical sequence: theoretical background, concept formation, strategic vectors determination. The proposed in the paper methodological approach to the regional innovation policy formation is based on the following principles of glocalization: systematicity, multilevel governance, cross-sectoral cooperation (a horizontal coordination), dialectics of global and local dimensions, priority of national interests, effectiveness, uniqueness, resource availability, sustainable development. The paper presents the results of the theoretical analysis of glocalization concept implementation in the innovation sphere, which showed that regional innovation policy formation in an era of glocalization is based on the concept of complementary combination of the glocal components of innovative development of the regions, namely: local, which is expressed through the effectiveness of innovation activity in a region, global (effectiveness of international cooperation in the innovation sphere) and regulating institutions. Regional innovation systems determined as a conceptual basis of regional innovation policy and global-local interactions. The importance of social capital for innovation development and practical implementation of glocalization concept is revealed. The research empirically confirms and theoretically proves that glocal innovative development of regions, although aimed at overcoming the disproportions of socio-economic levels, but at the expense of other instruments - that is the mobilization of its own reserves in accordance with an independently developed program of action. The research is relevant for Ukraine and other countries with powerful innovation potential in the aspect of building an effective national innovation system.
\end{abstract}

Keywords: glocalization, innovation development, innovation system, region, paradigm, social capital. JEL Codes: O38, R0, F60.

Copyright (C) 2021 Author(s), published by Vytautas Magnus University. This is an open access article distributed under the terms of the Creative Commons Attribution Non-Commercial 4.0 (CC BY-NC 4.0) license, which permits unrestricted use, distribution, and reproduction in any medium provided the original author and source are credited. The material cannot be used for commercial purposes. 


\section{Introduction}

Regions are important engines of economic development. In this research we consider regions as basic administrative units of a country at level NUTS 2, that are, due to the NUTS classification (Nomenclature of territorial units for statistics), basic regions for the application of regional policies.

Innovations are considered as a key source of competitive advantages and economic development of enterprises and regions. In a broad sense, innovation is the introduction of new elements (types, methods) into various types of human activity, which increase the effectiveness of this activity (Yakovets, 2004). In the article we understand innovations as newly created (applied) and improved competitive technologies, products or services, as well as organizational and technical solutions - production, administrative, commercial and others, that significantly improve the structure and quality of production and (or) the social sphere. Main task of regional innovation policy is to increase the ability of a region's socio-economic system to generate and consume innovations. The institutional basis for regional innovation policy is a regional innovation system - is a set of legislative, structural and functional components (institutions) that are involved in the generation and consumption of innovation and determine the legal, economic, organizational and social conditions for the innovation process.

According to world experience, regions have a significant potential for innovation development, and the task of research in this area is to identify the levers of activation of this potential, considering the paradigm shifts caused by the progress of the global economy. The research problem about regional innovation policy in this article is to investigate the global-local interactions of a region in order to use its synergy for innovation development.

The modern development of innovation processes in the regions is influenced by two trends that determine the dual nature of the spatial factor of regional innovation: the increasing role of global connections and the importance of geographical proximity of stakeholders of innovative development (Islankina, Fiyaksel, 2015).

Dialectics of global and local dimensions performs the glocalization concept. In the innovation sphere, the processes of glocalization are manifested in the complementarity of local factors of innovative development, in particular the unique innovation environment, human and social capital, with global factors of innovation development. The combination of regionalization and globalization complicates the functions of the region and necessitates regional innovation strategies. The success of the country's economic policy depends on successful combination of the global world trends and national / regional peculiarities of economic development.

The term "glocalization" was first used by Japanese economists in the 80's of the twentieth century to explain Japanese global marketing strategies, and then popularized by sociologist Roland Robertson in his book "Globalization: Social Theory and Global Culture" (Robertson R., 1992). Robertson R. explores the phenomenon of glocalization through the prism of transnational activity of subnational entities - regions. He rejects the essential polarity between global and local, for example, between economic globalization and local culture. Traditionally, local identities were invented and educated mainly through contacts with others, they were stimulated and formed predominantly by translocal interaction. Hence the conclusion that the dialectical combination of global and local, that is, glocalization, is a prerequisite for development. Globalization leads the world economy to degradation through all its inherent weaknesses. Localization also, even with its inherent progressive features, such as local differences, the revival of traditions, will not be able to provide development over time, because without global interaction, without contacts with representatives of other localities, it is doomed to extinction. Only a 
harmonious combination of these two phenomena, globalization and localization, leads to the development.

Turning to the theories of regional development, the idea of glocalization can be found in works of Enright M. (Enright, 2000), where, while exploring regional clusters, he draws attention to the coexistence and complementarity of two, at first glance, divergent tendencies: globalization of competition and localization of sources of competitive advantage. With regard to theories of innovation, its terminology, glocalization has not yet received widespread usage in the scientific lexicon, but conceptually it has been reflected in a number of studies devoted to the dual nature of innovation spatial factor (Bathelt et al, 2004; Scott, 1988). Glocalization concept were adopted to the innovation sphere in research of Benneworth P. \& Dassen A. (Benneworth, Dassen, 2011), where they explored global-local connectivity in regional innovation strategies.

Researchers by Jason Owen-Smith and Walter W. Powell (Owen-Smith, Powell, 2004) explored knowledge networks by the example of the Boston biotechnological cluster. They concluded that new information often occurs and is distributed not within local communities, but in strategic partnerships that have an international scale. Their advantage is to provide access to new knowledge that is not available within the local cluster. The disadvantage is the need for significant expenditure of human and financial resources to support connection channels.

The concept of "global buzz - local pipelines" (Bathelt et al, 2004) describes the process of emergence and circulation of "silent knowledge" as a result of close interaction and the exchange of information between enterprises, universities, research centers and other participants in the innovation process that are localized in the cluster. As a result of the dissemination of knowledge through local channels, a special ecosystem is formed in the cluster.

The provisions of this theory regarding the dissemination of knowledge among participants of the innovation process within the cluster are developing in the concept of social capital that is embodied in interpersonal relationships based on trust and cooperation among individuals, which enhances the innovative capacity of an entity through collective learning and synergies. According to the definition of the World Bank (Bebbington, 2004), social capital is the institutions, relationships and norms that form social and qualitative interactions, and social capital is distinguished along with physical, financial, human and natural capitals. Francis Fukuyama was one of the first to dedicate his work to uncovering the essence of social capital. Due to his definition, social capital is an instantiated informal norm that promotes cooperation between individuals (Fukuyama, 2001). F. Fukuyama draws attention to trust as a fundamental source of social capital formation, the presence of which in the system of socio-economic relations significantly influences the progress of countries in different directions. At the same time, its absence causes stagnation and failure of large-scale progressive reforms. Low levels of trust can adversely affect compliance with laws and regulations, reduce investor confidence and increase risks that also has an adverse effect on innovation. Philip Cooke examines the level of trust among local business entities within the cluster, the impact of cluster enterprises on the social sphere of the region. Representatives of this theory believe that it is the regional concentration that promotes the diffusion of innovation due to the high degree of trust among the cluster participants (Cooke, 2005). Rogers E. reveals the importance of proximity placement for diffusion of innovation. Diffusion is the process by which innovation

Copyright (C) 2021 Author(s), published by Vytautas Magnus University. This is an open access article distributed under the terms of the Creative Commons Attribution Non-Commercial 4.0 (CC BY-NC 4.0) license, which permits unrestricted use, distribution, and reproduction in any medium provided the original author and source are credited. The material cannot be used for commercial purposes. 
over time passes through certain channels to members of the social system (Rogers, 2003).

The main purpose of the research is to determine paradigm shift from traditional to modern regional innovation policy under conditions of glocalization based on the modern European research, experience of European countries' regions and reveal prospects of its implementation in Ukraine.

The research object is the regional innovation policy. The research subject includes glocalization concept of the regional innovation system as an approach to innovation development.

\section{Methods}

The viability and efficiency of the process of regulation of the innovation sphere of a region depends on the consistency of theoretical-methodological and methodical approaches with the key aspects of the new paradigm of regional innovation policy under conditions of the glocalization of economic processes. Theoretical and methodological approach to the regional innovation policy formation in an era of glocalization is based on the concept of complementary combination of the glocal components of innovative development of the regions, namely (Figure 1): - local, which is expressed through the effectiveness of innovation activity in a region; - global (effectiveness of international cooperation in the innovation sphere);

- regulating institutions.

It focuses on the actualized principles of the formation of regional innovation policy, strategic vectors of decentralization and regionalization of innovation sphere regulation, provision of innovative type of economic development of regions and provision of a market-oriented type of functioning and regulation of a regional innovation system in accordance with which the systemic institutional provision of variative regional innovation policy is formed and specifics of innovative development of regions are considered. 


\begin{tabular}{|c|c|c|}
\hline \multicolumn{3}{|c|}{ Theoretical-conceptual basis of methodology } \\
\hline \multicolumn{3}{|c|}{$\begin{array}{l}\text { Goal: assurance of progressive change of the socio-economic system of a region through } \\
\text { innovation development by creating conditions for the complementary combination of its } \\
\text { glocal components: local (the effectiveness of innovation activities), global (the } \\
\text { effectiveness of intemational activity in the innovation sphere of the region) and their } \\
\text { regulating institutions }\end{array}$} \\
\hline \\
\hline \multicolumn{3}{|c|}{ Tasks: } \\
\hline \\
\hline \multicolumn{3}{|c|}{\begin{tabular}{l|l|}
$\begin{array}{l}\text { Dexelopent of } \\
\text { innovation activities } \\
\text { in a region }\end{array}$ & $\begin{array}{l}\text { Development of } \\
\text { intemational activities in } \\
\text { innovation sphere of a } \\
\text { region }\end{array}$ \\
\end{tabular}} \\
\hline \multicolumn{3}{|c|}{$\begin{array}{l}\text { Concept of regional innovation policy on the basis of glocalization - is the creation of a } \\
\text { systemic institutional support for the combination of the glecal components of innovation } \\
\text { development considering the following principles: }\end{array}$} \\
\hline \multicolumn{3}{|c|}{ Principles } \\
\hline systematicity & & sustainable development \\
\hline \multirow{2}{*}{$\begin{array}{c}\text { priority of } \\
\text { national } \\
\text { intereste }\end{array}$} & $\begin{array}{c}\text { cross-sectoral } \\
\text { cooperation }\end{array}$ & $\begin{array}{l}\text { dialectics of global and } \\
\text { local dimensions }\end{array}$ \\
\hline & multilevel & effertiveness \\
\hline uniqueness & management & resource availability \\
\hline \multicolumn{3}{|r|}{ 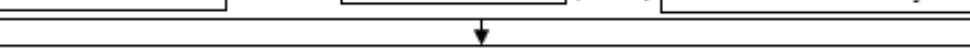 } \\
\hline \multicolumn{3}{|c|}{$\begin{array}{l}\text { Strategic vectors: } \\
\text { Implementation of a market-oriented type of operation and regulation of a regional } \\
\text { imnovation system; } \\
\text { Implementation of decentralization and regionalization into innovation sphere regulation; } \\
\text { Implementation of innovative type of economic development of regions; }\end{array}$} \\
\hline \multicolumn{3}{|c|}{$\downarrow$} \\
\hline \multicolumn{3}{|c|}{$\begin{array}{l}\text { Mechanisms and tools: regulatory, financial and non-financial stimulation, stimulation of } \\
\text { demand and supply of innovations, development of market infrastructure (financial, } \\
\text { industrial-technological, information, market development), accumulation of human and } \\
\text { social capital in the field of innovations }\end{array}$} \\
\hline
\end{tabular}

\section{Figure 1. Structural-logical diagram of the methodological approach to the regional innovation policy formation on the principles of glocalization}

The conducted theoretical study allows to distinguish the following principles of formation of regional innovation policy in terms of glocalization:

- systemacity: the system approach to innovation provides an effective interaction among the institutions of the innovation system and creates a favourable innovation ecosystem that encompasses favourable business conditions, an effective tax, trade and investment environment, the provision of key factors for innovation production and the implementation of special incentives for innovation activity;

- multilevel governance: multilevel innovation management is based on the subsidiarity approach and vertical coordination that encompasses the national, regional, subregional and baseline levels;

- cross-sectoral co-operation (a horizontal coordination): equal partnership and developed communication among all participants in the innovation process, namely: government, business, institutions of

Copyright $(0) 2021$ Author(s), published by Vytautas Magnus University. This is an open access article distributed under the terms of the Creative Commons Attribution Non-Commercial 4.0 (CC BY-NC 4.0) license, which permits unrestricted use, distribution, and reproduction in any medium provided the original author and source are credited. The material cannot be used for commercial purposes. 
generation of innovations, innovation consumers, as well as the interaction of regions with each other at the national and international levels - interregional and crossborder cooperation;

- dialectics of global and local dimensions;

- priority of national interests;

- effectiveness: achievement of quantitative and qualitative goals and objectives of innovation policy;

- uniqueness: considering features of innovation development of a region;

- resource availability: provision of innovation activity with appropriate resources (financial, human, technical etc.), both from local and global sources, by facilitating access and creating opportunities for their usage;

- sustainable development: considering socio-ecological and economic guidelines for innovation development.

In the article were applied the following research methods: theoretical generalization and retrospective analysis - to study evolutionary changes in regional innovation policy paradigms; discursive analysis - to determine the essence of regional innovation policy and glocalization of economic processes; analysis and synthesis - to summarize the world experience of formation and implementation of regional innovation policy; economic and statistical analysis - to diagnose the state of innovative development in Ukraine in terms of glocalization; methods of system analysis - to study the methodological foundations of the formation of regional innovation policy on the basis of glocalization.

\section{Results and Discussions}

The successes of the regions of the European Union (EU) countries in the field of innovation development confirm the effectiveness of their innovation policy. In the Global Innovation Index 2019 seven of the ten most innovative countries in the world are European countries: Switzerland $-1^{\text {st }}$ place, Sweden $-2^{\text {nd }}$, Netherlands $-4^{\text {th }}$, United Kingdom $-5^{\text {th }}$, Finland $-6^{\text {th }}$, Denmark $-7^{\text {th }}$, Germany $-9^{\text {th }}$ (Dutta et al., 2019).

Ukraine is at the initial stage of the formation of its regional innovation policy, and therefore the study of the European countries experience, the success of the regional innovation policy that contributed to their innovation growth, is of particular relevance.

The key indicators of effectiveness of innovation policy in Ukraine in comparison with the countries-leaders of innovation development in 2019 are presented in the Table 1. As it can be seen from the Table 1, the leader by the Global Innovation Index in 2019 is Switzerland, Ukraine occupies in this ranking 47th place. The global leader of innovation development - Switzerland - spends on science $3,4 \%$ of its (!) GDP, Japan $-3.2 \%$, Germany $-3.0 \%$, the USA $-2.8 \%$, Ukraine only $0.4 \%$.

Table 1. Global innovation index in Ukraine and in prominent innovative countries in 2019 (Note: compiled by the authors on the bases of Dutta et al., 2019)

\begin{tabular}{|c|c|c|c|c|}
\hline Countries & $\begin{array}{c}\text { Global Innovation } \\
\text { Index } \\
\text { (among 129 } \\
\text { countries) }\end{array}$ & $\begin{array}{c}\text { Output } \\
\text { rank }\end{array}$ & $\begin{array}{c}\text { Input } \\
\text { rank }\end{array}$ & $\begin{array}{c}\text { Gross expenditure on } \\
\text { R\&D, } \\
\text { \% GDP }\end{array}$ \\
\hline Switzerland & 1 & 1 & 2 & 3.4 \\
\hline USA & 3 & 6 & 3 & 2.8 \\
\hline Germany & 9 & 9 & 12 & 2.0 \\
\hline China & 14 & 5 & 26 & 3.2 \\
\hline Japan & 15 & 17 & 14 & 0.4 \\
\hline Ukraine & 47 & 36 & 82 & \\
\hline
\end{tabular}


The presence of Ukraine in the top 50 of the most innovative economies in the world is due to the high coefficient of innovative efficiency - the ratio of the result to resources in the field of innovations, according to which Ukraine occupied 5th place in the world in 2018 (in 2019 this indicator was not calculated). This is a Ukrainian phenomenon and evidence that even in conditions of degradation of innovative potential, low resource support, innovation activity in Ukraine is extremely effective and produces world-class innovation developments. The situation of inefficient innovation system enhanced by the poor collaboration among science, education and business in the innovation process (Table 2). It is proved by the low index of cooperation between universities and industry in Ukraine. An important condition for establishing links between all participants of the innovation process in the country is the cluster development. Ukraine lags far behind by this indicator; its cluster effectiveness coefficient Ukraine occupies the 98th place. Ukraine is also far behind the leaders of innovation by business expenditures on research. For example, in Switzerland this index is $63,5 \%$, while in Ukraine $-30,1 \%$.

\section{Table 2. Indicators of interaction between education, research and production in the innovation process in Ukraine and prominent innovative countries in 2019 \\ (Developed by the authors on the bases of Dutta et al., 2019)}

\begin{tabular}{|l|c|c|c|}
\hline Countries & $\begin{array}{c}\text { Gross expenditure in R\&D } \\
\text { financed by business, \% }\end{array}$ & $\begin{array}{c}\text { University/industry research } \\
\text { collaboration, rank }\end{array}$ & $\begin{array}{c}\text { State of cluster } \\
\text { development, rank }\end{array}$ \\
\hline Switzerland & 63.5 & 3 & 3 \\
\hline USA & 63.6 & 1 & 1 \\
\hline Germany & 65.2 & 6 & 28 \\
\hline China & 76.5 & 27 & 7 \\
\hline Japan & 78.3 & 18 & 98 \\
\hline Ukraine & 30.1 & 64 & 2 \\
\hline
\end{tabular}

The key to overcoming the existing problems in the innovation field of Ukraine is the orientation of the innovation policy towards building an effective national innovation system considering successful European experience and glocalization concept. The glocalization of economic processes in a region is expressed through three key components:

1) local - a unique socio-ecological and economic environment of the region. The formation of a favourable innovation environment is one of the main tasks of regional innovation policy. After all, local authorities will not be able to create an innovation-oriented regional economy on their own, but they can create conditions conducive to its growth, they can contribute to the formation of prerequisites for the establishment of partnerships, the removal of institutional and cultural barriers that impede the innovation activity of key players;

2) global - integration of regional socioeconomic systems, including a regional innovation system, into global networks, providing innovation activity with relevant resources (financial, human, technical, informational etc.) from both local and global sources, by facilitating access to them and creating opportunities for their usage. The limitation of the formation of an innovation environment on a certain territory leads to the "trap" of local communication, when all its reserves are exhausted and there is no further development of channels of communication and diffusion of innovations. This restriction can be overcome through usage of global

Copyright ( 2021 Author(s), published by Vytautas Magnus University. This is an open access article distributed under the terms of the Creative Commons Attribution Non-Commercial 4.0 (CC BY-NC 4.0) license, which permits unrestricted use, distribution, and reproduction in any medium provided the original author and source are credited. The material cannot be used for commercial purposes. 
channels that extend knowledge from local players to external counterparties and vice versa, going far beyond the territory of a region;

3) institutional - consolidation of the norms and customs of global-local interactions in the form of laws, organizations, institutions in order to complement the combination of global, national and local interests. Simple integration of regional players into global networks is not a guarantee of obtaining a region necessary resources for its development. Regional institutions that contribute to establishing strategic links with global networks, considering the interests of a region and its inhabitants, play an important role in this context. Regional innovation policy based on the principles of glocalization of economic processes - it is the strategic level of activity in relation to the establishment of an innovation type of economic development of the regions to ensure their competitiveness and progressive changes of the socio-economic system through the formation of institutional support for the complementary combination of global and local components of the glocal innovation development.

As the experience of leading countries in socio-economic development shows that the main prerequisite for rapid national development is the symbiosis of state, civil and economic vectors. A convincing example is the significant acceleration of the socio-economic development of the East Asian "tiger" countries (South Korea, Taiwan, Singapore, and Hong Kong). It is important that the governments of these countries not only mobilize capital and labour resources, but also provided activities aimed at mobilizing social capital, such as facilitating and equalizing access to education and information, reducing social inequality, and cooperation between the state and business. Most countries focus their innovation policies primarily on technology development, leaving the accumulation of social capital out of sight. Another example is South Korea, which is one of the world's innovation leaders, and whose national innovation system is based on intensive cooperation and social trust, which are among its main competitive advantages.

The experience of the European Union has shown that "soft", non-technical barriers to innovation development are important. "Innovation is not just about technology" - this idea runs through modern models for supporting innovation processes. Nontechnical barriers to effective innovation development include: inefficient management, weak communications, insufficient understanding of the requirements of the final consumer of innovations, lack of a favourable social climate for innovation, and so on. The transition to an innovative social-oriented economy involves building effective mechanisms for interaction among society, business and the state, aimed at coordinating the efforts of all participants, ensuring that the interests of various social groups of society and business are considered in the development and implementation of socio-economic policy. A society with a low level of trust and a lack of social capital is incapable for innovation.

In the practice of regional policy of the Soviet era, the principle of "equalization" was taken as the basis in order to overcome the economic backwardness of some historically formed territorial entities. Placing productive forces set the same goal. At first glance, such approach was effective, contributed to the socio-economic growth of depressed regions, but in comparison with more economically developed regions, the lag remained or even increased. Instead, this approach gave rise to passivity, lack of initiative, and rooting of dependent ideology of regions that did not seek their own development paths, but only relied on the support of the centre. However, in a new competitive context, when regions became independent participants in competitive processes under the conditions of economic development of innovation type, there is a need to find new approaches to the development of a region. A comparative analysis of the traditional paradigm and the modern paradigm of regional innovation policy under conditions of glocalization is presented in the Table 3 . 


\section{Table 3. Comparative characteristic of the traditional and modern paradigm of regional innovation policy under conditions of glocalization}

(Developed by the authors on the basis of Valentey, 2005; Regional Innovation Scoreboard, 2014, 2019; Regions and Innovation Policy, 2011)

\begin{tabular}{|c|c|c|}
\hline & $\begin{array}{c}\text { Traditional paradigm of regional } \\
\text { innovation policy }\end{array}$ & $\begin{array}{c}\text { Modern paradigm of regional innovation policy } \\
\text { under conditions of glocalization }\end{array}$ \\
\hline $\begin{array}{l}\text { Strategic } \\
\text { Goal }\end{array}$ & $\begin{array}{l}\text { Alignment of regions development } \\
\text { levels }\end{array}$ & Creating conditions for self-development of regions \\
\hline \multirow[t]{4}{*}{ Task } & \multicolumn{2}{|r|}{ Competitiveness } \\
\hline & $\begin{array}{l}- \text { Determination of numerous } \\
\text { elements of the socio-economic structure as } \\
\text { factors of competitiveness, that leads to } \\
\text { duplication of a number of uncoordinated } \\
\text { actions. }\end{array}$ & $\begin{array}{l}\text { - Innovations are considered as the main source of } \\
\text { competitiveness. } \\
\text { - Complementary combination of local and global } \\
\text { competitiveness factors. } \\
\text { - Smart specialisation of a region. } \\
\text { - Strengthening the social component in defining the } \\
\text { objectives of regional policy. }\end{array}$ \\
\hline & \multicolumn{2}{|r|}{ 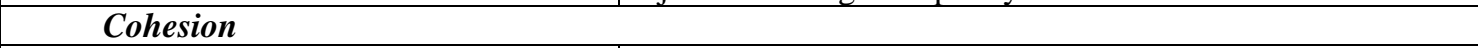 } \\
\hline & $\begin{array}{l}\text { - The key method is equalization that } \\
\text { led to reverse results - the increase of } \\
\text { disproportions, dispersal of resources, } \\
\text { dependent mentality }\end{array}$ & $\begin{array}{l}\text { - Strengthening cooperation between territories, as a } \\
\text { result - growth of flows of capital, labour force, knowledge, } \\
\text { innovations - the synergy of growth. }\end{array}$ \\
\hline Tools & $\begin{array}{l}\text { - Subsidies and state aid. } \\
\text { - Standardized tool set. }\end{array}$ & $\begin{array}{l}\text { - Creation of favourable business environment, social } \\
\text { capital accumulation, networking (clusters), and better } \\
\text { coordination. } \\
\quad-\quad \text { Integrated strategic planning of regional } \\
\text { development. } \\
\quad-\text { Differentiated approach to formation of a toolkit in } \\
\text { accordance with specificity of innovation development of a } \\
\text { region }\end{array}$ \\
\hline $\begin{array}{l}\text { Territorial } \\
\text { dimension }\end{array}$ & $\begin{array}{l}\text { - Homogeneous territorial approach } \\
\text { that does not consider regions' external and } \\
\text { internal diversity. } \\
\quad-\text { The priority of a sectoral approach } \\
\text { that does not consider the specifics of } \\
\text { regions, that's why it is called "poverty } \\
\text { algorithm". }\end{array}$ & $\begin{array}{l}\text { - Differentiated territorial approach: considering } \\
\text { diversity, coordination, multilevel governance. } \\
\quad \text { - Integrated programs aimed at supporting areas of } \\
\text { interterritorial interaction, instead of supporting spatial } \\
\text { integration. } \\
\quad-\text { Integration of regions into global production } \\
\text { networks, considering their local specificity }\end{array}$ \\
\hline $\begin{array}{l}\text { Objects of } \\
\text { regional } \\
\text { policy }\end{array}$ & $\begin{array}{l}\text { - Regions are administrative units. } \\
\text { - Specificity of urban and rural areas } \\
\text { is not considered. } \\
\text { - Region is a production complex. }\end{array}$ & $\begin{array}{l}\text { - Regions are functional units. } \\
\text { - Differentiated approach to different territories. The } \\
\text { policy is adapted to local conditions. } \\
\quad \text { - The object of regional innovation policy is not only } \\
\text { the region as a production complex and a regional innovation } \\
\text { system, but, above all, the population of a region with its } \\
\text { interests. }\end{array}$ \\
\hline $\begin{array}{l}\text { Entities of } \\
\text { regional } \\
\text { policy }\end{array}$ & - Central and regional authorities. & $\begin{array}{l}\text { - All levels of state management, representatives of } \\
\text { community and business. } \\
\text { - Region becomes not only the object of regional } \\
\text { policy, but also the entity engaged in regional policy. }\end{array}$ \\
\hline
\end{tabular}

The concept of the glocal innovative development of regions, although aimed at overcoming the disproportions of socioeconomic levels of regional development, but at the expense of other instruments - that is the mobilization of its own reserves in accordance with an independently developed program of action.

The glocalization of economic processes requires a change in the paradigm of regional innovation policy that consists in shift from the distribution of financial resources and the

Copyright (C) 2021 Author(s), published by Vytautas Magnus University. This is an open access article distributed under the terms of the Creative Commons Attribution Non-Commercial 4.0 (CC BY-NC 4.0) license, which permits unrestricted use, distribution, and reproduction in any medium provided the original author and source are credited. The material cannot be used for commercial purposes. 
widespread creation of innovation infrastructure to stimulative activities related to the concentration of human and social capital, the formation of a favourable business climate and institutional environment. Innovation policy should be varied in line with the specificity of the innovation development of each region.

\section{Conclusions}

Glocalization is a modern phenomenon, and therefore the study of innovation processes from the standpoint of glocalization allows to look at them from a new angle. The effectiveness of the process of regulating the innovation sphere of a region depends on the coherence of theoretical-methodological approaches with key aspects of the new paradigm of regional innovation policy in the conditions of glocalization of economic processes. The Ukrainian regional innovation policy is at the stage of its formation, is based on outdated principles of the traditional paradigm used since Soviet times, and does not meet modern socio-economic realities and requirements of innovation development of regions. To solve this scientific and applied problem, the theoretical and methodological approach to the formation of regional innovation policy on the basis of glocalization is proposed, which is based on the concept of complementary combination of glocal components of innovation development of regions, namely: local (the effectiveness of innovation activities), global (the effectiveness of international activity in the innovation sphere of a region) and their regulating institutions; and which focuses on the updated principles of regional innovation policy, strategic vectors of decentralization and regionalization of regulation of innovation.

The application of the methodological approach to the formation of regional innovation policy, proposed in the article, will help to ensure the effectiveness and systemacity of innovation policy in the regions of Ukraine and other countries with similar preconditions.

\section{Acknowledgements}

This publication was prepared within the framework of the scientific project "Organizational and economic mechanisms of increasing entrepreneurial activity in Ukraine" at the expense of the budget program "Support of priority areas of scientific research development" (КПКВК 6541230).

\section{References}

Bathelt, H., Malmberg, A. \& Maskell, P. (2004). Clusters and Knowledge: Local Buzz, Global Pipelines and the Process of Knowledge Creation. Progress in Human Geography, 28, $31-56$ [in English].

Bebbington, A., Guggenheim, S., Olson, E. \& Woolcock, M. (2004) Exploring Social Capital Debates at the World Bank. The Journal of Development Studies, 40:5, 33-64 [in English].

Benneworth, P., \& Dassen, A. (2011). Strengthening Global-Local Connectivity in Regional Innovation Strategies: Implications for Regional Innovation Policy. OECD Publishing [in English].

Cooke, Ph. (2005). Regionally Asymmetric Knowledge Capabilities and Open Innovation Exploring 'Globalisation 2' - A New Model of Industry Organization. Research Policy. 34(8), 1128-1149 [in English].

Dutta, S., Lanvin, B., \& Wunsch-Vincent S. (eds.) (2019). The Global Innovation Index 2019: Creating Healthy Lives - The Future of Medical Innovation. Retrieved from https://www.globalinnovationindex.org/gii-2019-report [in English]. Accessed: 24.05.2020.

Enright, M-J. (2000). The Globalization of Competition and the Localization of Competitive Advantage: Policies towards regional clustering. Basingstoke: MacMillan [in English]. English].

Fukuyama, F. (2001). Social Capital, Civil Society and Development. Third World Quarterly, 22, 7-20 [in

Islankina, E. A. \& Fiyakse,1 E. A. (2015). Glokalizaciya innovacij: rol klasterov i mezhdunarodnogo konteksta v regionalnom razvitii [Glocalization of innovation: the role of clusters and the international context in regional development]. Innovatsii - Innovations, 11, 64-74 [in Russian].

Owen-Smith, J., Powell, W.W. (2004). Knowledge Networks as Channels and Conduits: The Effects of Spillovers in the Boston Biotechnology Community. Organization Science. 15, 1, 5-21[in English]. 


\title{
Sciendo
}

\author{
Management Theory and Studies for Rural Business and Infrastructure Development \\ eISSN 2345-0355. 2021. Vol. 43. No. 2: 195-205 \\ Article DOI: https://doi.org/10.15544/mts.2021.16
}

Regional Innovation Scoreboard 2014. (2014). Belgium: European Commission, Directorate-General for Internal Market, Industry, Entrepreneurship and SMEs. Retrieved from https://op.europa.eu/en/publication-detail//publication/69a64699-18d7-40b9-8f92-1db3226cd2ec. Accessed: 24.05.2020.

Regional Innovation Scoreboard 2019. (2019). Belgium: European Commission, Directorate-General for Internal Market, Industry, Entrepreneurship and SMEs. Retrieved from https://ec.europa.eu/growth/sites/growth/files/ris2019.pdf. Accessed: 24.05.2020.

Regions and Innovation Policy. (2011). OECD Publishing [in English].

Robertson, R. (1992). Globalization: Social Theory and Global Culture. SAGE Publications [in English].

Rogers, E.M. (2003). Diffusion of innovations. New York: Free Press [in English].

Scott, A.J. (1988). New Industrial Spaces: Flexible Production Organization and Regional Development in North America and Western Europe. London: Pion [in English].

Valentey, S. (2005). Kontrinnovatsionnaya sreda rossiyskoy ekonomiki [The counter-innovation environment of the Russian economy]. Voprosy ekonomiki - Economic issues, 10, 133 [in Russian].

Yakovets, Yu.V. (2004) Epohal'nye innovacii XXI veka [Epic Innovations of the XXI Century]. M. [in Russian].

Copyright (C) 2021 Author(s), published by Vytautas Magnus University. This is an open access article distributed under the terms of the Creative Commons Attribution Non-Commercial 4.0 (CC BY-NC 4.0) license, which permits unrestricted use, distribution, and reproduction in any medium provided the original author and source are credited. The material cannot be used for commercial purposes. 